\title{
Литература:
}

CINGEROVÁ, N. - DULEBOVÁ, I.: Kultúrne regióny Ruska. Bratislava: Univerzita Komenského v Bratislave, 2021. 200 s. ISBN 978-80-223-5113-3. CINGEROVÁ, N. - DULEBOVÁ, I. - JALOVÁ, K.: Historické a kultúrne pamiatky Ruska. Heslár. Bratislava: Stimul. 2019. [online]. [cit. 24. 5. 2021]. <http://stella.uniba.sk/ texty.FiF_NCIDKJ_pamiatky_heslar.pdf>.

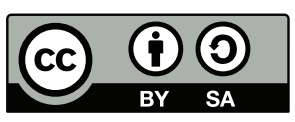

https://doi.org/10.5817/OS2021-2-10

\section{Jak jsou tvořena pojmenování kulturních rostlin v slovinských nářečích ${ }^{1}$}

KUMIN HORVAT, M.: Besedotvorni atlas slovenskih narečij. Kulturne rastline. Ljubljana: ZRC SAZU, 2018. ISBN 978-961-05-0088-9.

Slovinská jazykovědkyně Mojca Kumin Horvat se ve své knize Besedotvorni atlas slovenskih narečij. Kulturne rastline věnuje slovotvorným a lexikálním rozdílům nářeční slovní zásoby z okruhu kulturní rostliny. Zpracovává nářeční pojmenování planých ovocných stromů, nadzemních částí krmných plodin, druhů slámy, ovocných moštů a ovocných pálenek. Podkladem knihy byla autorčina disertační práce Morfološka struktura in geolingvistična interpretacija rastlinskih poimenovanj $v$ slovenskih narečjih $\mathrm{z}$ roku 2012.

Kniha formátu A4 sestává z 263 stran. Po obsahu následuje předmluva a úvod, dále šest kapitol. Knihu uzavírá seznam použité literatury, seznam zkratek a značek, soupis map a materiálových indexů a tabulka s naznačenou slovotvornou strukturou analyzovaných lexémů. $\mathrm{V}$ samém závěru knihy najdeme abecední rejstřík všech nářečních podob.

První kapitola Metody prípravy materiálu na s. 13 podává informace o materiálové základně. $\mathrm{V}$ knize $\mathrm{v}$ porovnání s disertační prací byla zhuštěna sít zkoumaných

1 Tento příspěvek vznikl s podporou dlouhodobého koncepčního rozvoje Ústavu pro jazyk český AV ČR, v. v. i., RVO: 68378092. 
bodů (z počtu 85 na 93) a byly vypuštěny položky nesouvisející s tematickým okruhem kulturní rostliny. Dále z původního materiálu zpracovaného v disertační práci byly při prŕpravě atlasu vyřazeny tzv. základní lexémy, např. názvy pro ovoce (jabolko, hruška, češnja). Autorka vysvětluje, že tato pojmenování nemohla být s ohledem na cíle práce do materiálu zahrnuta, protože vykazovala převážně rozdíly fonetické, nikoli lexikálně-slovotvorné. Celkem je v atlasu zpracováno 22 položek slovinského nářečního dotazníku ${ }^{2}$, publikovaného v časopisu Traditiones, který vydává Vědeckovýzkumné centrum Slovinské akademie věd a umění.

V první kapitole se také seznámíme se způsobem nářeční transkripce, najdeme zde podrobné rozdělení slovinských nářečí s jejich charakteristikou (včetně přehledné barevné mapy) a výčet zkoumaných obcí. U každé obce uvádí rok realizace nářečního výzkumu, jméno explorátora, iniciály (z důvodu ochrany osobních údajů nemohla být uvedena celá jména) a rok narození informátorů. Autorka zde též představuje metody sběru nářečního materiálu, který vedle vlastního výzkumu získala např́ílad i excerpcí seminárních a diplomových prací.

V druhé kapitole Teoretická východiska (s. 33) jsou vymezeny pojmy z oblasti slovotvorby, autorka se také zabývá motivovaností slov, předkládá přehled a popis sufixů zpracovávaných nářečních lexémů a uvádí př́íklady literatury, která se této tematice věnuje.

Následuje kapitola Metody mapování a komentování nářečního materiálu (s. 47). Po krátkém úvodu o vývoji mapování v slovinské dialektogii jsou představeny metody mapování použité $\mathrm{v}$ tomto atlase. Vyskytují se $\mathrm{v}$ něm dva základní typy map: slovotvorné a lexikálně-slovotvorné. Všechny slovotvorné mapy v knize jsou svodné a jsou pouze značkové, prezentují jazykový materiál pomocí geometrických symbolů a jejich vnitřní a vnější modifikace, zatímco lexikálně-slovotvorné mapy jsou vypracovány kombinovanou mapovací technikou, užívají značky, nápisy a izoglosy.

Další kapitola Mapy a komentáře (s.59) se již věnuje mapovému zpracování nářečního materiálu a komentářům. Materiál je rozdělen do pěti sémantických skupin, z nichž každá je zpracována v samostatné podkapitole (v závorkách uvádíme její název ve slovinštině a výčet položek mapovaných a komentovaných $\mathrm{v}$ rámci daného okruhu): Plané ovocné stromy (Divja sadna drevesa: Divja jablana, Divja hruška, Divja češnja, Divje sadno drevo (splošno poimenovanje)), Nadzemní části krmných plodin (Nadzemni deli krmnih rastlin: Repni listi, Pesni listi, Korenjevi listi, Krompirjevi listi), Sláma (Slama: Fižolova slama, Koruzna slama, Pšenična slama, fečmenova slama, Ržena slama, Prosena slama, Ovsena slama, Ajdova slama), Ovocný mošt (Sadni mošt: Jabolčni mošt, Hruškov mošt), Ovocná pálenka (Sadno žganje: Fabolčno žganje, Hruškovo žganje, Češnjevo žganje, Žganje (splošno poimenovanje)). 
Všechny tyto podkapitoly jsou koncipovány jednotně. Každá obsahuje několik svodných map a po jedné lexikálně-slovotvorné mapě pro každý sledovaný lexém, mapy jsou doprovázeny komentáři. Naprŕiklad podkapitola Divja sadna drevesa obsahuje svodnou mapu Strukturní typy lexémů, zobrazující územní rozšírení všech sufixů, kterými jsou utvořena nářeční pojmenování $\mathrm{v}$ této sémantické skupině (tj. pro planou jabloň, planou hrušeň, planou třešeň a obecné pojmenování pro planý ovocný strom). Následující čtyři mapy ukazují distribuci nejčetnějších sufixů: Přípona -(j)ak, Př́ípona -ica, Přípona -(j)ača, Přípona -ika. Další mapa se týká víceslovných pojmenování. $Z$ mapy je možné snadno vyčíst, že nejčastější jsou spojení s př́ivlastkem divji, a to divja jablana, divja hruška, divja češnja. Následuje část zaměřená již konkrétně na jednotlivé sledované výrazy sémantického okruhu, tedy na planou jabloň, planou hrušeň, planou třešeň a planý ovocný strom. Každá z těchto položek je představena na lexikálně-slovotvorné mapě doprovázené komentářem, připojen je též soupis nářečních podob v jednotlivých lokalitách.

$\mathrm{V}$ rámci sémantických okruhů jsou na samostatných mapách zpracovány tyto sufixy: pro okruh Plané ovocné stromy: -(j)ak, -ica, -(j)ača, -ika; pro okruh Nadzemní části krmných plodin: -əc, -(n)ik, -ica, -ka, -je; pro okruh Sláma: -ica, -ka, -ina, -išče; pro okruh Ovocný mošt: -əc, -ək, -(n)ik, -ica; pro okruh Ovocná pálenka: -əc, -ica, -n-je. Přípony, které netvoří areál nebo je jejich distribuce řídká, nejsou zobrazeny na samostatných mapách, jsou pouze popsány v komentářích.

V páté a šesté kapitole Závěr a Souhrn (s.221 a 225) provedla autorka vyhodnocení slovotvorné analýzy nářečního materiálu jednotlivých sémantických okruhů a předložila závěry vyplývající z jejího zkoumání. Mimo jiné uvádí, že nářeční materiál okruhu kulturní rostliny je lexikálně a slovotvorně natolik různorodý, že je možné na základě toho podat slovotvorné charakteristiky nářečí, určit produktivnost a systémovou a zeměpisnou distribuci slovotvorných prostředků.

Velkým kladem této publikace je barevné provedení map, které velmi usnadňuje zejména čtení svodných map. I takto je tedy orientace v tomto typu map zprvu obtížná, ale po důkladném prostudování legendy, kde vedle symbolů najdeme i informaci, která barva symbolů $\mathrm{v}$ mapě přísluší které položce, lze $\mathrm{z}$ map vyčíst velmi mnoho. Například v kapitole Divja sadna drevesa se pro položku divja jablana užívá červená barva symbolů, pro položku divja hruška žlutá barva, pro položku divja češnja zelená a pro položku divje sadno drevo barva černá. Vlastně vždy stačí zjistit přiřazení barev pouze u první mapy jednotlivých sémantických okruhů, protože toto barevné schéma je jednotné pro všechny mapy v rámci okruhu.

Autorčin cíl provést geolingvistickou analýzu slovotvorně diferencovaného materiálu a na základě toho ukázat, že strukturní typy lexémů a jednotlivé slovotvorné 
prostředky mají v nářečích svoje typické areály, byl zcela jistě dosažen. Tato práce může posloužit jako předloha pro další slovotvorné anylýzy nářečního lexika z jiných sémantických okruhů.

Petra Přadková

\section{Literatura:}

BENEDIK, F.: Vprašalnice za zbiranje narečnega gradiva. Traditiones. 1994, 23, s. 87-142. ISSN $0352-0447$.

KUMIN HORVAT, M.: Besedotvorni atlas slovenskih narečij. Kulturne rastline. Ljubljana: ZRC SAZU, 2018. ISBN 978-961-05-0088-9.

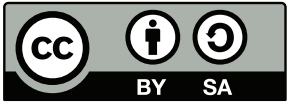

Toto dílo Ize užít v souladu s licenčními podmínkami Creative Commons BY-SA 4.0 International (<https:// creativecommons.org/licenses/by-sa/4.0/legalcode>). Uvedené se nevztahuje na díla či prvky (např. obrazovou či fotografickou dokumentaci), které jsou v díle užity na základě smluvní licence nebo výjimky či omezení príslušných práv. 